\title{
Winter Runoff of Nitrogen and Phosphorus from a Rotational Pen Design with Suckler Cows
}

\author{
Eva Salomon 1*, Helena Aronsson ${ }^{2}$, Gunnar Torstensson², Barbro Ulén ${ }^{2}$ \\ ${ }^{1} \mathrm{JTI}-$ Swedish Institute of Agricultural and Environmental Engineering, Uppsala, Sweden \\ ${ }^{2}$ Biogeophysics and Water Quality, Department of Soil and Environment, Swedish University of Agricultural \\ Sciences, Uppsala, Sweden \\ Email: ${ }^{*}$ eva.salomon@jti.se
}

Received 12 September 2015; accepted 25 October 2015; published 28 October 2015

Copyright (C) 2015 by authors and Scientific Research Publishing Inc.

This work is licensed under the Creative Commons Attribution International License (CC BY). http://creativecommons.org/licenses/by/4.0/

c) (i) Open Access

\begin{abstract}
Keeping beef cattle outdoors during winter reduces costs and improves animal welfare, but increases the risk of nitrogen $(\mathrm{N})$ and phosphorus $(\mathrm{P})$ runoff losses. This study evaluated a rotational pen design on grassland with two groups of suckler cows given access to an expanding staying area and a new feeding area each week ( 72 cattle ha $\left.^{-1}\right)$, with one month's stay per pen. The spatial distribution of excreta and effects on $N$ and $P$ surface runoff was evaluated during six months. The total excreta loads corresponded to $500 \mathrm{~kg} \cdot \mathrm{N} \cdot \mathrm{ha}^{-1}$ and $50 \mathrm{~kg} \cdot \mathrm{P} \cdot \mathrm{ha} \mathrm{a}^{-1}$. New feeding areas did not distribute excretions evenly, which resulted in the highest proportion of excretions (31\%) occurring in the first week's sub-area. The topsoil had significantly higher amounts of mineral-N, mainly as NH4-N (29 - $\left.81 \mathrm{~kg} \cdot \mathrm{ha}^{-1}\right)$, than an unaffected area (13 kg·ha-1). Mean total runoff losses were similar for both groups (1.4 kg.P.ha-1 and $\left.9.0 \mathrm{~kg} \cdot \mathrm{N} \cdot \mathrm{ha}^{-1}\right)$. Around $78 \%$ of $\mathrm{N}$ and $70 \%$ of $P$ runoff losses occurred during the month with cattle present. During the first two weeks with heavy rain, $N$ and $P$ runoff losses were $50 \%$ higher from an area with suckler cows than a corresponding vegetated sub-area without cows. The study design did not provide a sufficient distribution of excretions and a high animal density in combination with trampling resulted in unacceptable $N$ and $P$ run-off losses. An environmentally friendly design would need to include frequent moving of all equipment and access to larger areas.
\end{abstract}

\section{Keywords}

N, P, Organic Carbon, Outdoor Pen, Trampling, Surface Runoff

\footnotetext{
${ }^{*}$ Corresponding author.
}

How to cite this paper: Salomon, E., Aronsson, H., Torstensson, G. and Ulén, B. (2015) Winter Runoff of Nitrogen and Phosphorus from a Rotational Pen Design with Suckler Cows. Agricultural Sciences, 6, 1248-1261. 


\section{Introduction}

Grazing by cattle is needed during the summer period to preserve about 450,000 hectares of semi-natural grassland of high biodiversity in Sweden, but declining economic margins for Swedish beef producers are making it too expensive to house these cattle in conventional winter housing.

High animal density on outdoor areas has been shown to result in large net inputs of nutrients to the soil and an increased risk of nitrogen $(\mathrm{N})$ leaching [1]. High animal density in combination with continuous cattle rearing at the same site for several years has been shown to result in surface runoff with high total phosphorus (P) concentrations and with a high proportion of $\mathrm{P}$ in dissolved form, which is highly bioavailable [2]. The limiting animal density in Sweden is based on an average manure application corresponding to $22 \mathrm{~kg} \cdot \mathrm{P} \cdot \mathrm{ha}^{-1}$ over a five-year crop rotation [3]. For suckler cows, this corresponds to 0.7 animal units per hectare [4], i.e. it is permitted to keep 3.5 suckler cows per hectare in one year out of five, but data on how beef farmers implement this regulation in outdoor rearing systems are lacking. According to Swedish agricultural statistics, when animal manure is applied to arable crops the amount of P supplied with the manure is too high, with $16 \%$ of Swedish arable land receiving $>40 \mathrm{~kg} \cdot \mathrm{P} \cdot \mathrm{ha}^{-1}$ [5]. The risk of nutrient leaching depends not only on the amounts of $\mathrm{N}$ and $\mathrm{P}$ applied, but also the timing of application. Application of manure during autumn and winter is highly restricted under Swedish regulations, as this high-risk period is known to contribute large $\mathrm{N}$ leaching loads to waters [6].

The majority of excreta are deposited where cattle spend most of their time, i.e. in staying areas and feeding areas, resulting in $\mathrm{N}$ point loads [2] [7]. Keeping cattle or horses in permanent pens reinforces this point load effect and also increases the trampling effect [8] [9]. For example, in a permanent winter pen system used for 10 years with an animal density of about 13 cows ha $^{-1}$, the herd instinct to gather in feeding and staying areas was found to result in significantly higher ammonium- $\mathrm{N}\left(\mathrm{NH}_{4}-\mathrm{N}\right)$ concentrations in topsoil of those areas compared with moderately and slightly affected areas [8]. This concentration of trampling and excreta increases the risk of soil erosion and runoff of $\mathrm{N}$ and $\mathrm{P}$ in periods with high precipitation or snowmelt [10], especially on soils with low infiltration and poor structure. Sweden has erosion-sensitive silty soils in central and northern areas [11], a fact which needs to be considered when cattle are kept outdoors.

Replacing cattle houses with simpler types of shelters and keeping cattle outdoors on arable land during winter could reduce the costs [12]. Keeping cattle outdoors can also improve their health and allows them to express natural behaviours [13]. A rotational pen system whereby cattle are given continuous access to new staying and feeding areas has been proposed as a solution to decrease the environmental impact. This system can result in a more even distribution of excreta, thus avoiding harmful point loads of $\mathrm{N}$ and $\mathrm{P}$ [14] [15]. For example, a rotational system for over-wintering beef cattle with 1.5 months staying time per pen resulted in lower amounts of surface runoff, sediment losses and organic-N losses than a system with a continuous six-month stay per pen [15]. Thus there is a need to improve the rotational pen design and evaluate its potential to prevent $\mathrm{N}$ and $\mathrm{P}$ surface runoff losses [2].

In the present study, we examined a rotational over-wintering pen system for suckler cows that was included in a crop rotation with temporary grassland in the final winter before ploughing and reseeding. With a three-year clover/grass ley, cereals and under sown ley rotation, the cows would only return to the same arable area every fifth year at most. The cows were provided with a new pen each month and, within the pen, a new feeding area in an expanding staying area each week, in order to mitigate animal impacts such as trampling causing destroyed vegetation cover and point loads of excreta. This system would reduce the investment, labour and land costs by $50 \%$ compared with conventional indoor housing [16]. Specific objectives of the study were to investigate the impacts of: 1) expanding staying area on the spatial distribution of excreted $\mathrm{N}$ and $\mathrm{P} ; 2$ ) animal density on surface runoff of $\mathrm{N}$ and $\mathrm{P}$; and 3) expanding staying area on surface runoff of $\mathrm{N}$ and $\mathrm{P}$.

\section{Materials and Methods}

\subsection{Climate and Soil at the Site}

The study was conducted on a commercial organic beef farm with a 200 suckle cow herd in western Sweden $\left(59^{\circ} 20^{\prime} \mathrm{N} ; 13^{\circ} 7^{\prime} \mathrm{E}\right)$. The site was chosen to represent extensive beef production in the forest district of the country [17]. Main forage species used in grassland production are Festuca pratensis (Huds.), Lolium perenne (L.), Phleum pratense (L.), Trifolium pratense (L.) and Trifolium repens (L). Mean annual temperature at the site is $5.7^{\circ} \mathrm{C}$ and mean annual precipitation is $662 \mathrm{~mm}$ [18]. The dominant soil texture in arable land in this region is 
clay loam and silt loam [19]. The topsoil (0 - $30 \mathrm{~cm}$ depth) at the experimental site consists of $36 \%$ clay, 37\% silt and $27 \%$ sand [20]. The total-N, total-C and total-Pcontent before the suckler cows entered the experimental pens was on average $0.2 \%, 2.1 \%$ and $<0.001 \%$ of dry matter content, respectively, and the $\mathrm{pH}$ in topsoil was on average 6.1 [21].

\subsection{Experimental Design}

The study was performed using cross-breed beef suckler cows. Two sizes of groups (large, $n=34$; small, $n=17$ ) but with the same average animal density ( 72 dry suckler cows ha ${ }^{-1}$ ) were included in the experimental design, in order to evaluate whether a larger herd congregating and causing trampling effects in feeding and staying areas would constitute a greater risk of surface runoff than a smaller herd. At the experimental start, average weight was $386 \mathrm{~kg} \mathrm{cow}^{-1}$ and $388 \mathrm{~kg} \mathrm{cow}^{-1}$ in the large and the small group, respectively. Average age was 21 months $\mathrm{cow}^{-1}$ and 20 months $\mathrm{cow}^{-1}$ in the large and the small group, respectively. For the pen with the large group, surface runoff from two halves of the pen area was collected (Large 1 and Large 2). For the pen with the small group, surface runoff from the whole pen area was collected (Small 1). The two groups were kept in pens, with four experimental sub-areas within the pen, for one month (8 November-9 December) on an eight-year-old clover/grass ley harvested twice per grazing season. The year before the ley was not fertilised but cut. In the growing season before the experiment the ley was harvested as round bale silage. A number of silage bales corresponding to feed requirements of the suckler cows in the experiment were left after harvest on the area of the pens. During the experiment feed-racks and fences were moved manually every week, resulting in new feeding areas, new silage and an expanding staying area, Figure 1. With this rotational pen system, point loads of excreted $\mathrm{N}$ and $\mathrm{P}$ from suckler cows were expected to even out over time, despite the different numbers of animal units in sub-areas, Table 1 . The cows had free access to grass/clover silage, drinking water and a weather shelter with a full canvas roof, wind netting on three sides and straw bedding. New straw bales was moved by tractor to the pens every week and spread manually in the weather shelter, corresponding to $5 \mathrm{~kg}$ per cow and day. When the cows had access to a new sub-area, they grazed available green matter for some hours. To further reduce the impact of trampling on soil, strips of synthetic polymer grid matting were placed around the water tank, at the entrance to the weather shelter and as a path between the weather shelter and feeding area. There was no machine traffic in the pen.

\subsection{Experimental Set-Up}

\subsubsection{Pen Balance}

Pen nutrient balance of the elements $\mathrm{N}$ and $\mathrm{P}$ for the period with cattle present was calculated using Equation (1) and was assumed to be the total amount of $\mathrm{N}$ and $\mathrm{P}$ excreted [22].

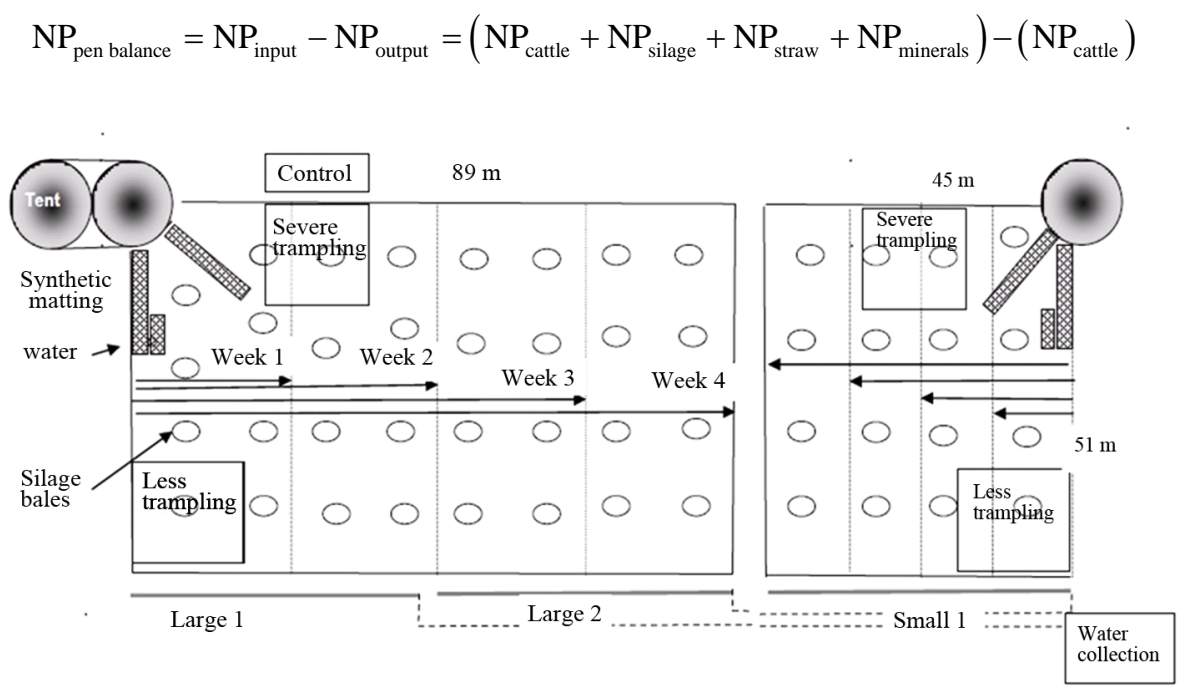

Figure 1. Experimental pens used in the study, in which cattle had access to a new feeding area and an expanding staying area each week. 
Table 1. Density of suckle cows (animal units (au) ha $\left.{ }^{-1}\right)^{\mathrm{a}}$ in the total staying area of the two pens (including canvas shelter, water tank, synthetic matting, feeding and staying areas) in each week of the month-long study.

\begin{tabular}{|c|c|c|c|c|c|c|c|c|}
\hline \multirow[b]{3}{*}{ Time period } & \multicolumn{4}{|c|}{$\underline{\mathrm{au} \mathrm{ha}^{-1}}$} & & & & \\
\hline & \multicolumn{4}{|c|}{$\underline{\text { Small } 1}$} & \multicolumn{2}{|c|}{$\underline{\text { Large } 1}$} & \multicolumn{2}{|c|}{ Large 2} \\
\hline & Area 1 & Area 2 & Area 3 & Area 4 & Area 1 & Area 2 & Area 3 & Area 4 \\
\hline Week 1 & 3.4 & 0 & 0 & 0 & 3.3 & 0 & 0 & 0 \\
\hline Week 2 & 5.3 & 1.9 & 0 & 0 & 5.2 & 1.8 & 0 & 0 \\
\hline Week 3 & 6.5 & 3.1 & 1.3 & 0 & 6.4 & 3.1 & 1.3 & 0 \\
\hline Week 4 & 7.3 & 3.9 & 2.0 & 0.7 & 7.4 & 4.0 & 2.2 & 0.9 \\
\hline
\end{tabular}

${ }^{\mathrm{a}}$ Calculated as: $\mathrm{nFt} / \mathrm{A}$, where $\mathrm{n}=$ number of animals, $\mathrm{F}=$ animal unit factor $(0.7$ units $=1$ suckle cow $), \mathrm{t}=$ stocking days and $\mathrm{A}=$ size of stocking/source area (ha).

The amounts of silage and minerals fed and the amount of straw used as litter were weighed at the start. Eachindividual cow was weighed at the start and end of the experimental period.

\subsubsection{Point Loads of $\mathrm{N}$ and $\mathrm{P}$}

The pen area was divided into several sub-areas corresponding to the activity that the cows performed there (Table 2). Cow behaviour was recorded simultaneously in both groups by three observers during two consecutive days per week (Day 1: 11 - $12 \mathrm{am}, 13$ - 17 pm, Day 2: 7 - $11 \mathrm{am}, 12$ - $13 \mathrm{pm}$ ) for three weeks [23]. Among other behaviours, defecation and urination were recorded on these occasions. Each defecation and urination event was then marked on a plan of the pen, including the different sub-areas. Using the total number of defecation and urination events per $10 \mathrm{~m}^{2}$ and per 10 cows, it was possible to calculate and compare the proportion of excreta deposited on each sub-area [24]. The respective proportion of deposition for each sub-area was then used to calculate the proportion of the total amount of $\mathrm{N}$ and $\mathrm{P}$ excreted that loaded the sub-area, giving a quantitative estimation of heterogeneity in the $\mathrm{N}$ and $\mathrm{P}$ load within the pen [25].

\subsubsection{Weather Conditions, Water Sampling and Analysis}

The air temperature at $1.85 \mathrm{~m}$ height, soil temperature at $2-5 \mathrm{~cm}$ depth and precipitation were measured hourly with a weather station (Vaisala Weather Transmitter WXT 510, Finland) at the experimental pens from 1 September to 20 April. The pens for both the large and small groups were situated in an area with a gentle slope of $2 \%$ to the lower long side, where surface runoff was collected, Figure 2(b). Surface runoff was measured and water sampling conducted from 1 September to 20 April. The gutters collecting surface runoff were installed one year before and calibrated before the experimental period. There were no differences in runoff volume and related loads of $\mathrm{C}, \mathrm{N}$ and $\mathrm{P}$ in analysed samples before 8 November and the cows entered the pens (data are not shown). The experimental areas can therefore be assumed to have the same conditions.

Surface runoff and related loads of $\mathrm{N}$ and $\mathrm{P}$ from the pens were determined using $0.4 \mathrm{~m}$ wide gutters of sheet metal counter-sunk $0.15 \mathrm{~m}$ into the soil to collect water flowing from the pens. For the pen with the small group of cattle, surface runoff from the whole pen area was collected with a gutter which covered the lower long side of the pen (Small 1 in Figure 1). For the pen with the large group, surface runoff from the two halves of the pen area was collected by separate gutters at the lower long side (Large 1 and Large 2 in Figure 1). Week 1 and week 2 surface runoff was measured from two areas with the same animal density (Small 1 and Large 1) and also from a ley crop area without cows (Large 2), Table 1. Week 3 and week 4 surface runoff was measured from two areas with the same animal density (Small 1 and combined Large 1 and Large 2), Table 1.

The water was conducted in sealed pipes from the gutter to an underground station, where the water flow was continuously recorded by tipping-buckets connected to a data logger. Flow-proportional water samples (15 mL per occasion) were taken using a peristaltic pump after every $0.2 \mathrm{~mm}$ discharge. Water samples were collected in individual polyethylene bottles for Large 1, Large 2 and Small 1, which were emptied every 2 weeks during drainage periods for analyses of total-C, total- $\mathrm{N}, \mathrm{NO}_{3}-\mathrm{N}$, total-P, $\mathrm{PO}_{4}-\mathrm{P}$ and particulate $\mathrm{P}(\mathrm{PP})$. To determine the 


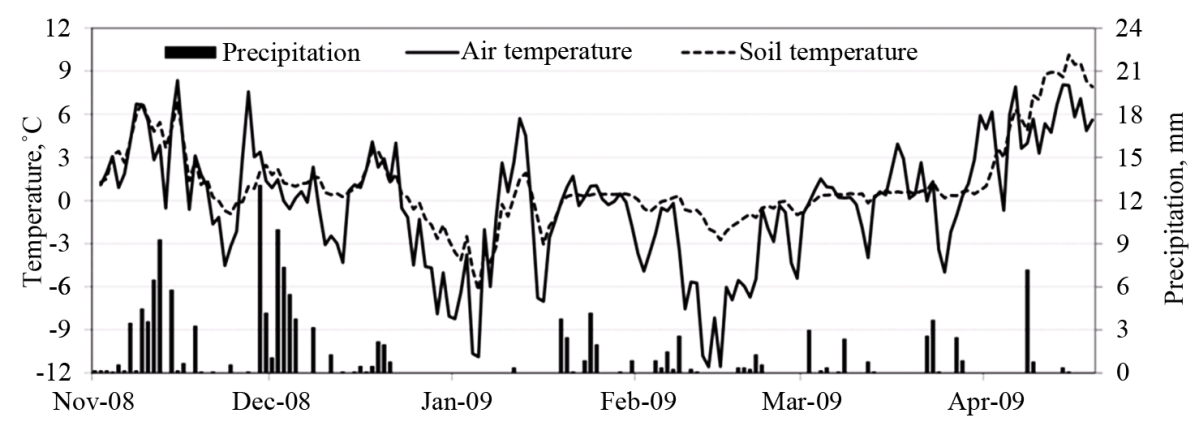

(a)

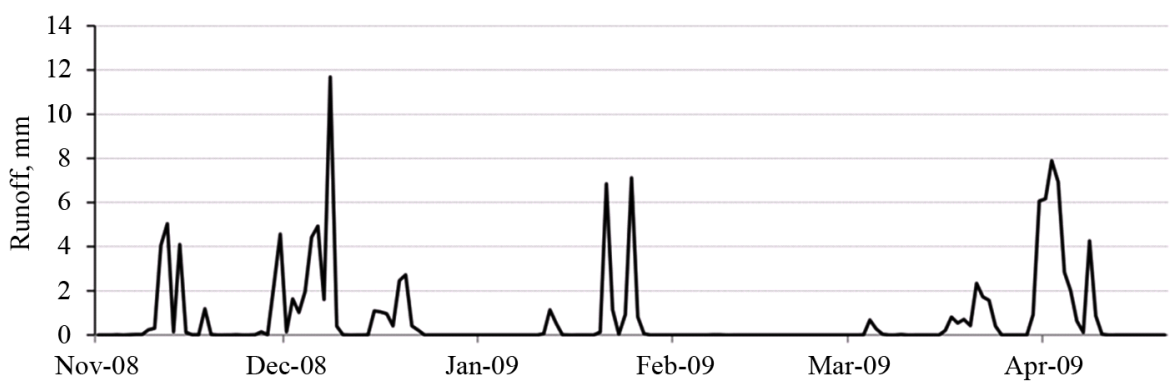

(b)

Figure 2. Daily precipitation and daily mean air and soil (2 - $5 \mathrm{~cm}$ depth) temperature (a) and daily mean measured runoff from the pens (b). Cattle were present from Nov-08 to Dec-09.

Table 2. Total $\mathrm{N}$ and $\mathrm{P}$ balance, proportion of excreta and $\mathrm{N}$ and $\mathrm{P}$ loads in sub-areas for each pen and group of suckler cows (small, $n=17$; large, $n=34$ ).

\begin{tabular}{|c|c|c|c|c|c|c|}
\hline \multirow{3}{*}{$\operatorname{Pen}^{\mathrm{a}}$} & \multicolumn{3}{|c|}{$\underline{\text { Small } 1}$} & \multicolumn{3}{|c|}{ Large $1+2$} \\
\hline & \multirow[t]{2}{*}{ Excreta (\%) } & $\underline{N \text { load }}$ & $\underline{\text { P load }}$ & \multirow[t]{2}{*}{ Excreta (\%) } & $\underline{\text { N load }}$ & $\underline{\text { P load }}$ \\
\hline & & $\left(\mathrm{kg} \cdot \mathrm{ha}^{-1}\right)$ & & & \multicolumn{2}{|l|}{$\left(\mathrm{kg} \cdot \mathrm{ha}^{-1}\right)$} \\
\hline Total balance & 100 & 478 & 47 & 100 & 486 & 49 \\
\hline Canvas shelter area & 11 & 783 & 78 & 17 & 1395 & 142 \\
\hline Drinking water area & 2 & 480 & 48 & 1 & 699 & 71 \\
\hline Week 1 FS area & 15 & 363 & 36 & 17 & 371 & 38 \\
\hline Week 2 FS area & 30 & 622 & 62 & 26 & 544 & 55 \\
\hline Week 3 FS area & 25 & 504 & 50 & 19 & 390 & 40 \\
\hline Week 4 FS area & 14 & 283 & 28 & 18 & 364 & 37 \\
\hline Synthetic matting & 3 & 1078 & 107 & 2 & 1154 & 117 \\
\hline
\end{tabular}

${ }^{\mathrm{a}} \mathrm{FS}=$ Feeding and staying area.

total-N and total-C concentrations, a combustion catalytic oxidation method was used (Shimadzu TOC- $\mathrm{V}_{\mathrm{CPH}}+$ TNM-1) according to European standard (SS-EN 12260-1). For N analyses, all N was first converted to nitrate $\left(\mathrm{NO}_{3}\right)$. The $\mathrm{NO}_{3}-\mathrm{N}$ concentration was then determined by flow injection analysis (Tecator AB, Höganäs, Sweden) according to the colorimetric cadmium reduction method [26]. Total-P was determined photometrically [27] on unfiltered and filtered samples after being oxidised with $\mathrm{K}_{2} \mathrm{~S}_{2} \mathrm{O}_{8}$, where the difference between these fractions was regarded as $\mathrm{PP} \mathrm{PO}_{4}-\mathrm{P}$ was analysed on filtered samples (Sartorius membrane filters; $0.2 \mu \mathrm{m}$ pore diameter). The difference between Total-P and $\mathrm{PO}_{4}-\mathrm{P}$ in unfiltered samples was defined as dissolved organic $\mathrm{P}$ (DOP).

The runoff loads of $\mathrm{C}, \mathrm{N}$ and $\mathrm{P}$ were calculated by multiplying the concentrations in each sample for the 2-week period prior to the sampling date by the daily amount of water runoff. The values were accumulated to 
2-week runoff loads and then divided by 2-week water runoff amounts to give mean concentrations.

\subsection{Cattle, Feed, Straw and Soil Sampling and Analysis}

Data on the general content of $\mathrm{N}$ and P per kg body weight in adult cattle [22] were multiplied by cattle weight. Ten bulk samples of silage and four bulk samples of straw (1 - 2 litres per sample) were randomly selected from the silage bales and straw bales used and analysed for $\mathrm{N}$ and P. Sub-samples of $1 \mathrm{~g}$ were digested by automatic wet digestion (Tecator Digestion System) using solvents [28] [29] and analysis of P was performed by inductively coupled plasma-atomic emission spectrometry (ICP-AES; JY 50P, JY Horiba, Division JobinYvon, Longgjumeau, France). Nitrogen was determined by an automated Kjeldahl procedure (Tecator AB, Höganäs, Sweden). Data on N and P content in the mineral supplements fed were taken from the manufacturer's specifications.

The topsoil (0 - $30 \mathrm{~cm}$ depth) was sampled just before and just after the presence of cattle in the Large $(1+2)$ and Small pens, and in a control outside the pens. Just after the cattle left two smaller areas $(15 \mathrm{~m} \times 15 \mathrm{~m})$ within the pen areas, representing one severely trampled (ST) and one less trampled (LS), were sampled, Figure 1. A total of 24 soil cores were collected in each sampling area and pooled to form four composite samples [30]. Half of each composite sample was frozen $\left(-20^{\circ} \mathrm{C}\right)$ and the other halfair-dried at $18^{\circ} \mathrm{C}$ before analysis. Bulk samples of frozen soil were milled and extracted with $2 \mathrm{M} \mathrm{KCl}$ [31]. Thereafter, $\mathrm{NH}_{4}-\mathrm{N}$ and $\mathrm{NO}_{3}-\mathrm{N}$ were determined colorimetrically with an auto analyser (TRAACS 800; method no. ST9002-NH4D and ST9002-NO3D). Values were converted to $\mathrm{kg} \cdot \mathrm{N} \cdot \mathrm{ha}^{-1}$ by taking account of the actual soil moisture content and the mean bulk density of the soil $\left(1.25 \mathrm{~kg} \cdot \mathrm{dm}^{-3}\right)$ [32]. The bulk samples of air-dried soil were analysed for soil texture [20], exchangeable soil P [33]-[35] and non-exchangeable P [33]. Total $\mathrm{N}$ and total $\mathrm{C}$ were determined as a percentage of the soil dry matter content.

\subsection{Statistical Analysis}

Amounts of $\mathrm{NH}_{4}-\mathrm{N}$ and $\mathrm{NO}_{3}-\mathrm{N}$ in topsoil at each sampling area (ST, LS, control) just after the experimental period were statistically analysed using a general linear model with a one factor design, with the factor "area" fixed [36].

\section{Results}

\subsection{Pen Balance and Point Loads of $\mathrm{N}$ and $\mathrm{P}$}

The total nutrient inputs for the 31-day study period were similar, and corresponded to an average load of 478 $\mathrm{kg} \cdot \mathrm{N} \cdot \mathrm{ha}^{-1}$ and $47 \mathrm{~kg} \cdot \mathrm{P} \cdot \mathrm{ha}^{-1}$ for the small group and $486 \mathrm{~kg} \cdot \mathrm{N} \cdot \mathrm{ha}^{-1}$ and $49 \mathrm{~kg} \cdot \mathrm{P} \cdot \mathrm{ha}^{-1}$ for the large group, Table 2. The largest proportion of excreta, corresponding to $84 \%$ of total excreta for the small group and $80 \%$ for the large group, was deposited on the total area for feeding and staying during week 1 to week 4 . This area also occupied the largest proportion by area of each pen, corresponding to $90 \%$ for the small group and $92 \%$ for the large group. Within weeks, the $\mathrm{N}$ and $\mathrm{P}$ loads in each feeding and staying area were quite similar for both groups. Over time, the $\mathrm{N}$ and $\mathrm{P}$ loads decreased due to expanding feeding and staying areas each week. The exception was the feeding and staying area in week 1 , but that area also included the canvas shelter, water tank and synthetic matting during the whole study period, Figure 1. The drinking water areas and the areas with synthetic matting received only small proportions of excreta, but as they were small areas the $\mathrm{N}$ and $\mathrm{P}$ loads were considerable. The proportion of excreta deposited in the shelter area was higher for the large group (17\%) than the small group (11\%), which resulted in higher $\mathrm{N}$ and $\mathrm{P}$ loads for the large group despite the shelter area in both pens having the same animal density.

\subsection{Soil N and P Concentrations}

In analysed soil samples there was no clear impact of the nutrient loads supplied with excreta on the content of exchangeable $\mathrm{P}$, non-exchangeable $\mathrm{P}$, total- $\mathrm{N}$ and total- $\mathrm{C}$ in the topsoil when values at the start of the experimental period were compared with those for severely trampled, less trampled and control areas at the end. On average, the amount of exchangeable $\mathrm{P}$ in topsoil was $38 \mathrm{mg} \cdot \mathrm{kg}^{-1}$ and that of non-exchangeable $\mathrm{P}$ was 508 $\mathrm{mg} \cdot \mathrm{kg}^{-1}$. The total-N and total-C content was comparable to the content at the start. 
Just before the cattle entered the pens, the mineral $\mathrm{N}$ content in topsoil was 40 and $47 \mathrm{~kg} \cdot \mathrm{ha}^{-1}$, with the majority in the form of $\mathrm{NO}_{3}-\mathrm{N}$, Table 3. After the cattle left the pens, the majority of mineral $\mathrm{N}$ in topsoil was in the form of $\mathrm{NH}_{4}-\mathrm{N}$. The sampled pen area that was severely trampled had significantly higher amounts of $\mathrm{NH}_{4}-\mathrm{N}$ than the less trampled and control areas, corresponding to $80 \mathrm{~kg} \cdot \mathrm{ha}^{-1}$ for the small group and $45 \mathrm{~kg} \cdot \mathrm{ha}^{-1}$ for the large group. The less trampled pen areas also had significantly higher amounts of $\mathrm{NH}_{4}-\mathrm{N}$ than the controls, corresponding to $36 \mathrm{~kg} \cdot \mathrm{ha}^{-1}$ in the small group and $28 \mathrm{~kg} \cdot \mathrm{ha}^{-1}$ in the large group. At the end, a minor amount of mineral $\mathrm{N}$ in topsoil was in the form of $\mathrm{NO}_{3}-\mathrm{N}$ and there was no clear difference in $\mathrm{NO}_{3}-\mathrm{N}$ concentration between areas, Table 3.

\subsection{Surface Water Runoff}

Runoff was low until the topsoil was water-saturated in mid-November due to intensive rainfall events, Figure 2. The period from November to December was wet (95 mm rain). During January to March there were some extended frost events and snowfalls but no snow cover, interrupted by short periods with temperatures above $0^{\circ} \mathrm{C}$.

Total runoff from the pen with the small group of suckle cows (Small 1) from the start of November until mid-April amounted to $150 \mathrm{~mm}$, with the main runoff periods during November to December and during snowmelt in March-April, Figure 3. Total runoff from the pen area with the large group of suckle cows (Large 1) was similar in the first two weeks, corresponding to $140 \mathrm{~mm}$. Total runoff from the pen area with ley vegetation (Large 2) was about 50\% lower in the first two weeks, corresponding to $80 \mathrm{~mm}$. Although cows were admitted to that area in last two weeks of the study (Large 2), the moderating effect of the initial vegetation cover persisted in subsequent months. Runoff was somewhat underestimated for the Large 1 area, since there was some ice blocking of the sampling pipes during February to March.

\subsection{Phosphorus Concentrations}

Total-P concentrations were generally high, but with great variation (range $0.2-2.5 \mathrm{mg} \cdot \mathrm{L}^{-1}$ ), and increased rapidly when the cows entered the pens. Particulate-P constituted the main fraction lost in runoff during the period with intensive runoff (November-December), with concentrations of about 1.0 and $1.1 \mathrm{mg} \cdot \mathrm{L}^{-1}$ in mid-November in water from pen areas with cows present (Small 1 and Large 1; Figure 4). However, the concentration in runoff

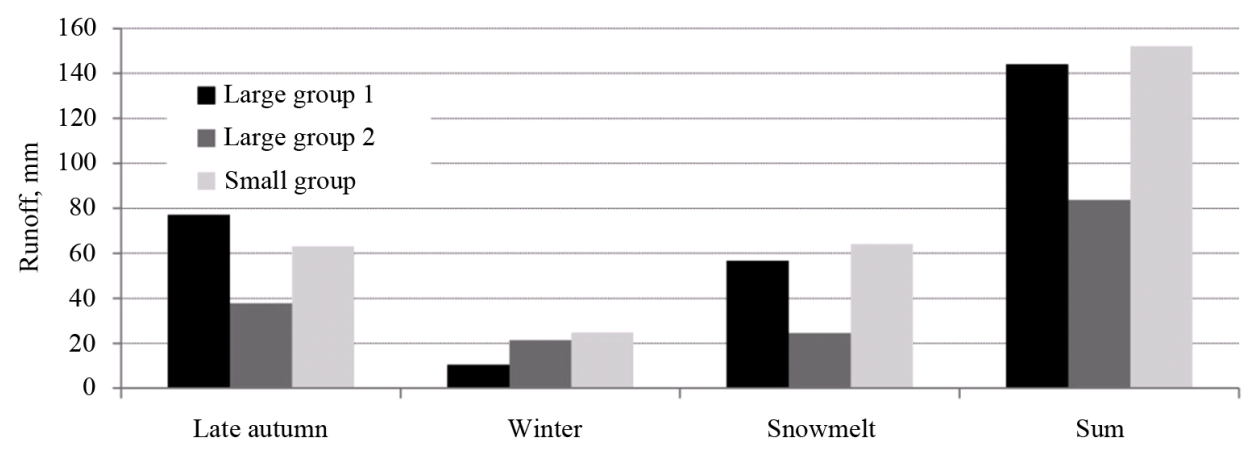

Figure 3. Surface runoff from the two areas of the large group pen and the small group pen between November-December 2008, January-February 2009 and March-April 2009, and total surface runoff.

Table 3. Total $\mathrm{N}$ and $\mathrm{P}$ balance, proportion of excreta and $\mathrm{N}$ and $\mathrm{P}$ loads in sub-areas for each pen and group of suckler cows (small, $\mathrm{n}=17$; large, $\mathrm{n}=34$ ).

\begin{tabular}{|c|c|c|c|c|c|c|c|c|}
\hline \multirow{3}{*}{$\begin{array}{l}\text { Mineral-N } \\
\mathrm{Kg} \cdot \mathrm{ha}^{-1}\end{array}$} & \multicolumn{2}{|c|}{$\underline{\text { At start }}$} & \multicolumn{6}{|c|}{$\underline{\text { Atend }}^{\mathrm{a}}$} \\
\hline & \multirow{2}{*}{ Small group } & \multirow{2}{*}{ Large group } & \multicolumn{3}{|c|}{$\underline{\text { Small group }}$} & \multicolumn{3}{|c|}{ Large group } \\
\hline & & & $\mathrm{ST}^{\mathrm{b}}$ & $\mathrm{LS}^{\mathrm{c}}$ & Control & $\mathrm{ST}^{\mathrm{b}}$ & $\mathrm{LS}^{\mathrm{c}}$ & Control \\
\hline $\mathrm{NH}_{4}-\mathrm{N}$ & 10 & 7 & $80 a$ & $36 b$ & $11 \mathrm{c}$ & $45 a$ & $28 b$ & $11 \mathrm{c}$ \\
\hline $\mathrm{NO}_{3}-\mathrm{N}$ & 37 & 33 & $1 b$ & $1 b$ & $2 a$ & $<1 \mathrm{c}$ & $1 b$ & $2 a$ \\
\hline
\end{tabular}

${ }^{a}$ Within each cattle group at the end, LS means $(n=4)$ with different subscripts are significantly different $(p<0.05)$. bST $=$ severely trampled area. cLS = less trampled area. 


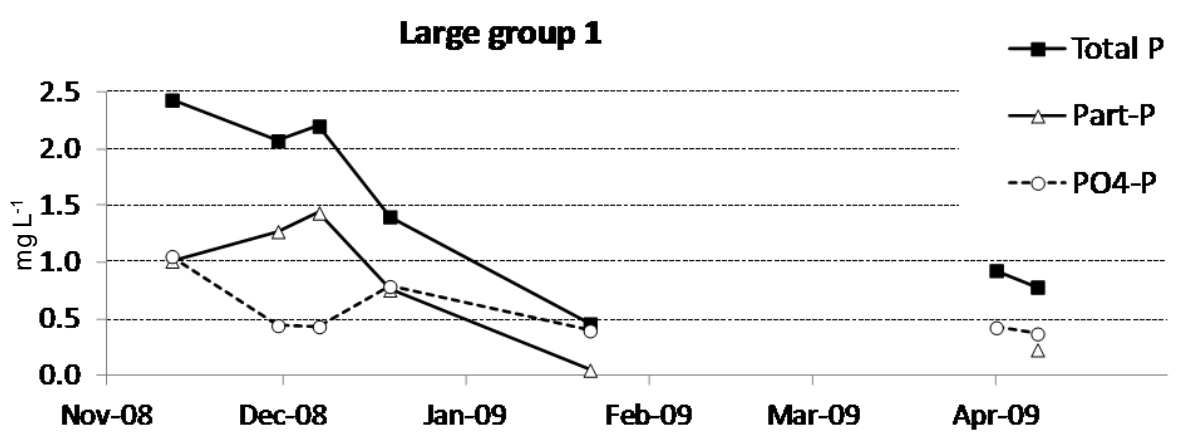

(a)

Large group 2

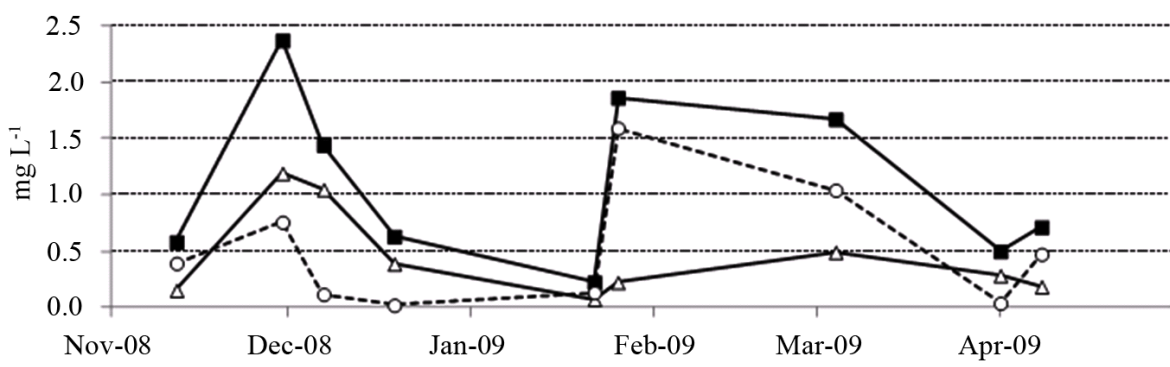

(b)

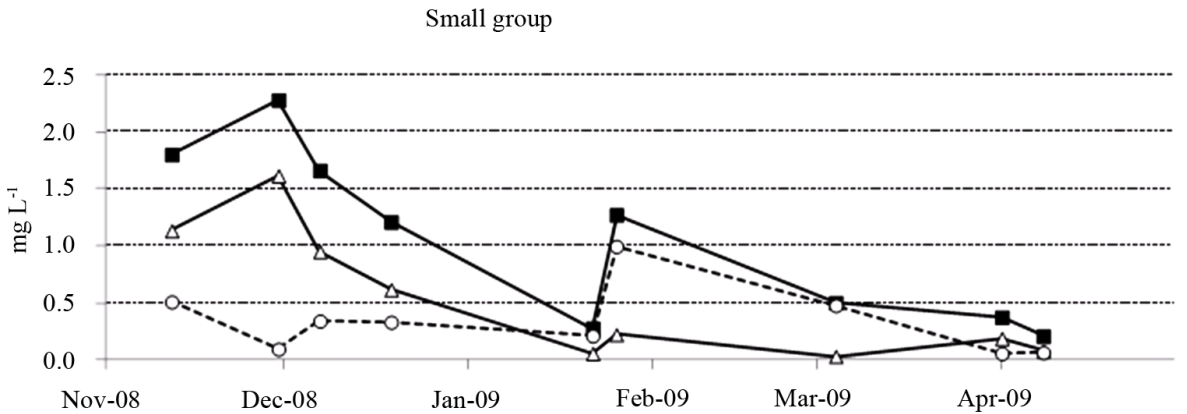

(c)

Figure 4. Measured concentration $\left(\mathrm{mg} \cdot \mathrm{L}^{-1}\right.$ ) of total-P, particulate-P (PP) and dissolved $\mathrm{P}$ $\left(\mathrm{PO}_{4}-\mathrm{P}\right)$, in the different pen areas. The values shown represent the moment when half the runoff water recorded during the actual sampling event had passed.

was only $0.15 \mathrm{mg} \cdot \mathrm{L}^{-1}$ in the part of the pen with ley vegetation and no cows present in the first two weeks (Large 2). The PP concentrations then increased during December and decreased over the following months as the runoff peaks declined. In contrast, the concentration of dissolved $\mathrm{P}\left(\mathrm{PO}_{4}-\mathrm{P}\right)$ in runoff from Large 2 and Small 1 increased from about $0.5 \mathrm{mg} \cdot \mathrm{L}^{-1}$ in November-December to about $1.3 \mathrm{mg} \cdot \mathrm{L}^{-1}$ at the end of January, after a period of soil frost.

\subsection{Nitrogen and Organic Carbon Concentrations}

The concentrations of total- $\mathrm{N}$ in runoff followed a similar pattern to the $\mathrm{P}$ concentrations, i.e. they rapidly increased $\left(10.5-13.2 \mathrm{mg} \cdot \mathrm{L}^{-1}\right)$ when the cows entered the pen sub-areas on 8 November (Small 1 and Large 1 ) and 20 November (Large 2), Figure 5. During the period November-December, when the highest total-N concentrations were found, $\mathrm{NO}_{3}-\mathrm{N}$ constituted less than $1 \%$ of the $\mathrm{N}$ found in runoff water. The majority of $\mathrm{N}$ was probably in the form of organic $\mathrm{N}$, since the measured total organic $\mathrm{C}$ concentration followed a similar pattern to total-N during this period, Figure 6. Some of the $\mathrm{N}$ was probably also in $\mathrm{NH}_{4}-\mathrm{N}$ form, originating from excreta, but this was not analysed. However, after the cold period in January, $\mathrm{NO}_{3}-\mathrm{N}$ concentrations increased, Figure 5. 


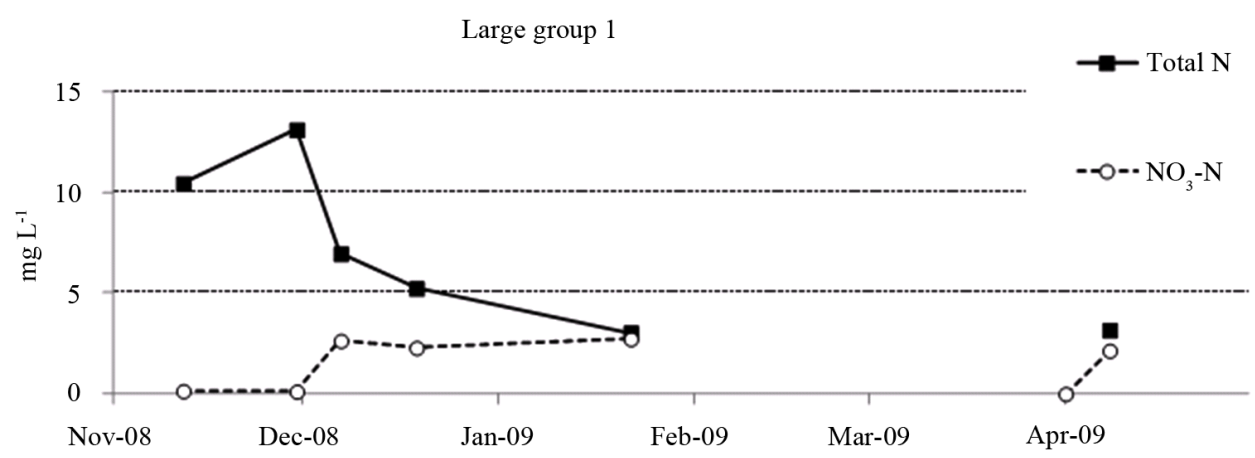

(a)

Large group 2

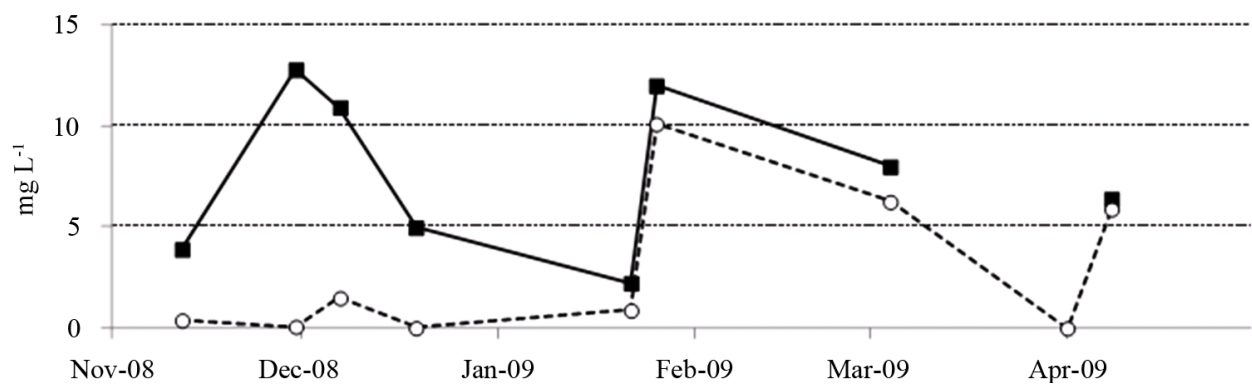

(b)

Small group

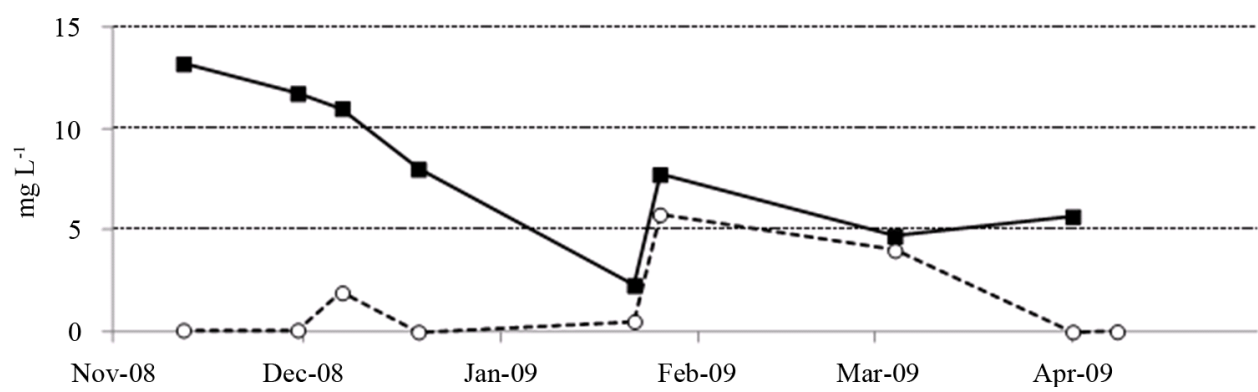

(c)

Figure 5. Measured concentrations $\left(\mathrm{mg} \cdot \mathrm{L}^{-1}\right.$ ) of total- $\mathrm{N}$ and $\mathrm{NO}_{3}-\mathrm{N}$ in the different areas. The values shown represent the moment when half the runoff water recorded during the actual sampling event had passed.

\subsection{Runoff Losses of $\mathrm{N}$ and $\mathrm{P}$}

About $50 \%$ of the total amount of surface runoff, $75 \%-80 \%$ of $\mathrm{N}$ transport and $60 \%-80 \%$ of $\mathrm{P}$ transport occurred during November-December.

Mean losses of total-P were quite similar for both group sizes, 1.5 and $1.3 \mathrm{~kg} \cdot \mathrm{ha}^{-1}$ for the combined Large 1 and Large 2, and Small 1, respectively, Table 4. In contrast, total-N losses were lower from the combined Large 1 and Large 2 group pen $\left(6.7 \mathrm{~kg} \cdot \mathrm{ha}^{-1}\right)$ than from the small group pen $\left(11.3 \mathrm{~kg} \cdot \mathrm{ha}{ }^{-1}\right)$. Even though $\mathrm{NO}_{3}-\mathrm{N}$ concentrations increased considerably during the end of the period, they constituted only $8 \%-18 \%$ of total-N. For P, $25 \%$ - 35\% was in dissolved form.

\section{Discussion}

The conditions for moderate nutrient losses from the pen system were favourable: the eight-year-old grass ley was well developed; strips of polymer grid matting were laid around the water tank, at the entrance to the 


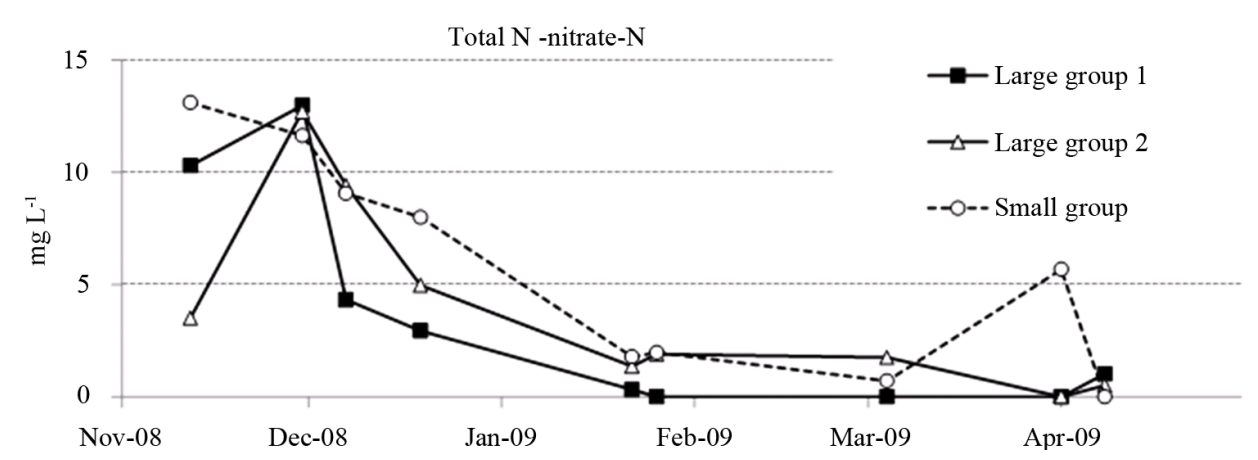

(a)

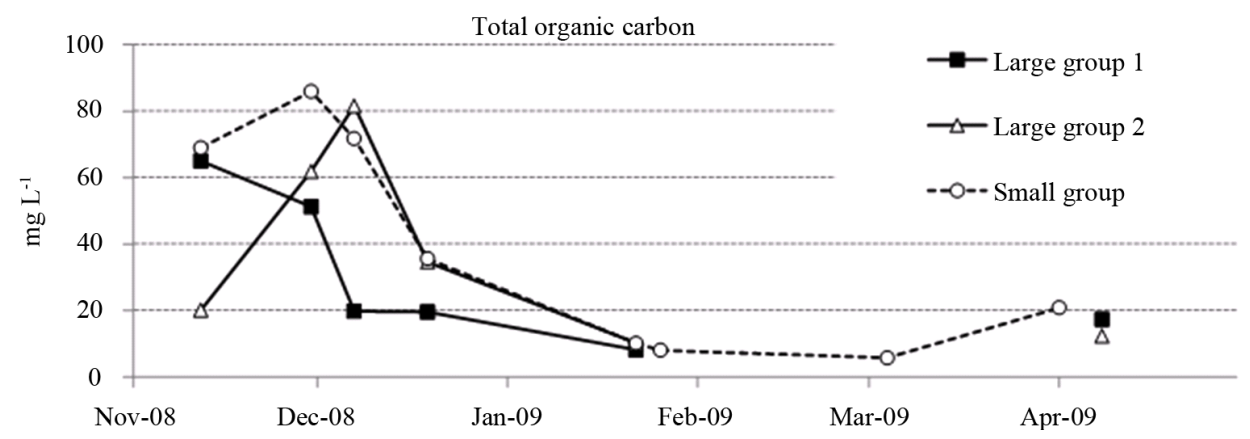

(b)

Figure 6. Measured concentrations (mg $\cdot \mathrm{L}^{-1}$ ) of total organic carbon and the difference between total-N and nitrate-N (assumed to consist mainly of organic $\mathrm{N}$ ). The values shown represent the moment when half the runoff water recorded during the actual sampling event had passed.

Table 4. Surface runoff of different forms of $\mathrm{N}$ and $\mathrm{P}\left(\mathrm{kg} \cdot \mathrm{ha}^{-1}\right)$ in pens. The mean for Large 1 and Large 2 is given for comparison with Small 1 during the whole experimental period.

\begin{tabular}{ccccccc}
\hline Pens & $\mathrm{PO}_{4}-\mathrm{P}$ & Part-P & $\mathrm{DOP}$ & Total-P & $\mathrm{NO}_{3}-\mathrm{N}$ & Total-N \\
\hline Large 1 & 0.8 & 1.1 & 0.4 & $\mathbf{2 . 2}$ & 1.8 & $\mathbf{8 . 4}$ \\
Large 2 & 0.2 & 0.4 & 0.1 & $\mathbf{0 . 6}$ & 0.6 & $\mathbf{5 . 0}$ \\
Mean of Large areas & 0.5 & 0.7 & 0.3 & $\mathbf{1 . 5}$ & 1.2 & $\mathbf{6 . 7}$ \\
Small 1 & 0.3 & 0.7 & 0.3 & $\mathbf{1 . 3}$ & 0.9 & $\mathbf{1 1 . 3}$ \\
\hline
\end{tabular}

weather shelter and on two paths; and there was no machine traffic in the pens. Except for muddy hooves, the cows in the pens were clean due to their consistent use of the synthetic matting when walking to feed and shelter and their frequent use of the straw bedding in the weather shelter for lying. Thus the system design achieved high animal welfare in this aspect [23].

However, the system proved to create the worst case scenario concerning environmental impact owing to heavy and prolonged rain, in combination with excretion and trampling on the unstable soil at the site. The stability of soil aggregates and the related risk of erosion is closely correlated to the clay, silt and humus content of the soil [37], and high erosion losses from silty clay loams and loams in e.g. Norway have been reported [38]. Eight years of ley production were expected to have promoted good aggregate stability of the topsoil studied here, according to findings for another silty soil in central Sweden [11]. However, the dense grass sward did not protect the soil against trampling by the cows and the soil surface was bare within two weeks. Within four weeks, the soil was worked by hooves into a viscous mass down to $0.1 \mathrm{~m}$ depth in area 1 , Table 1 .

The high runoff losses of $\mathrm{N}$ and $\mathrm{P}$ presumably derived from high excreta loads in combination with destruction of the soil surface. The first two experimental weeks demonstrated the inhibitory effect of ley vegetation in very wet conditions, resulting in 50\% of runoff from Large 2 without cows compared with Large 1 and Small 1 with the same cow density present, Figure 3 . After the cows left the pens, the inhibitory effect on runoff per- 
sisted in Large 2 during winter and snowmelt compared with Small 1 and Large 1, where the trampling during the conditions in the first two weeks reduced the infiltration capacity of the soil over the whole experimental period. To avoid negative environmental impacts during heavy rainfall periods in winter in regions with silty soils, a practical countermeasure could be to keep cattle indoors some days, or move them to paddocks with stabilised surfaces.

Another reason why the Large 1 area was more severely trampled than the Large 2 area was that the weather shelter and drinking water tank were situated in Large 1, so the cows moved back and forth to these facilities during all four weeks. Similar animal behaviour was seen in the Small 1 pen, in which these facilities were situated within the week 1 sub-area. Thus, the positive effect of moving feeding areas each week to reduce trampling effects and point loads of $\mathrm{N}$ and $\mathrm{P}$ was to some extent not fully exploited due to the daily use of the shelter and drinking water source by the cows. This was apparent as higher total runoff and particulate losses of $\mathrm{N}$ and P from the Large 1 area compared with the Large 2 area (Table 4). The small areas with synthetic matting protected the soil surface at the part of the pen where the cows stood for around $15 \%$ of their time, but the cows were in the eating area and excreted and trampled the soil around feed racks for more than $50 \%$ of the time [23]. Therefore the synthetic matting did not have any major effect in inhibiting losses of $\mathrm{N}$ and $\mathrm{P}$. The losses from the Large 1 area were even somewhat underestimated due to ice blocking the pipe in March. During that period, there were about $45 \mathrm{~mm}$ of surface runoff from the Small 1 area, with related transport of $0.14 \mathrm{~kg}$ total-P and 2.6 $\mathrm{kg}$ total- $\mathrm{N} \mathrm{ha}^{-1}$. Thus total losses from the Large 1 area were probably at least $10 \mathrm{~kg}$ total- $\mathrm{N} \mathrm{ha}{ }^{-1}$ and $2.3 \mathrm{~kg}$ total-P ha ${ }^{-1}$.

According to the nutrient balance, the excreta supplied about $50 \mathrm{~kg} \mathrm{P}$ and $500 \mathrm{~kg} \cdot \mathrm{N} \cdot \mathrm{ha}^{-1}$. Although applied under unsuitable conditions, this amount is not remarkably high for P. For the rotational system investigated here, where suckler cows are intended to be kept on the same pen area every five years, the P load was acceptable according to Swedish regulations [3]. However, the P load was not environmentally acceptable and it resulted in higher runoff losses of PP than those found in a study of a horse paddock on a heavy clay soil in eastern Sweden, where leaching to tile drains was measured [39]. In that study, PP losses through the soil were small, but elevated concentrations of dissolved $\mathrm{P}$ were detected year-around in drainage water compared with that from an ungrazed nearby pasture. In the present study, the concentration of $\mathrm{PO}_{4}-\mathrm{P}$ in surface runoff from Large 2 in the first two weeks corresponded to $0.5 \mathrm{mg} \cdot \mathrm{L}^{-1}$. This was a higher release of $\mathrm{PO}_{4}-\mathrm{P}$ from an unfertilised vegetation than the $0.1 \mathrm{mg} \cdot \mathrm{mg} \cdot \mathrm{L}^{-1}$ measured in December in a three-year study in Finland [40]. However, it was well below the $2-5 \mathrm{mg} \cdot \mathrm{L}^{-1}$ in surface runoff from a grass ley fertilised annually with P [41].

For $\mathrm{N}$, the load of about $500 \mathrm{~kg} \cdot \mathrm{N} \cdot \mathrm{ha}^{-1}$ from a stocking density of 72 cattle ha ${ }^{-1}$ greatly exceeded the maximum permissible $\mathrm{N}$ application rate of $170 \mathrm{~kg} \cdot \mathrm{N} \cdot \mathrm{ha}^{-1}$ and year stated in the EU Nitrate Directive [42]. Furthermore, the excreted $\mathrm{N}$ was applied in late autumn and winter, when leaching losses can be considerable [6] [43]. There was also a considerable increase in mineral $\mathrm{N}$ in topsoil in severely trampled parts of the large and small group pens compared with control areas after one month of cows being present. Severely trampled parts also fell within the feeding and staying area in week 1 and 2, where the greatest proportion (45\%) of excretions occurred. Similarly, a study of a winter pen used for 10 years and stocked with about 23 cows ha ${ }^{-1}$ found that the highest accumulated amounts were in topsoil close to the cow house, although the actual amounts recorded were more than seven-fold higher than in the present study [8]. With the pen design used in the present study, the two different group sizes had similar excretion behaviour except that the large group had a $6 \%$ higher proportion of excretions in the canvas shelter than the small group. Such differences in group behaviour can be difficult to predict, but can be expected. In another study with pigs given access to outdoor pens, one group excreted around 19\% of total excreted $\mathrm{N}$ and $\mathrm{P}$ amounts in the indoor pen and another group around $41 \%$ [25].

This study showed that a rotating pen and feeding area can be a promising strategy for preventing high point loads of $\mathrm{N}$ and $\mathrm{P}$ being supplied with excreta for both group sizes tested, although the overall load of 500 $\mathrm{kg} \cdot \mathrm{N} \cdot \mathrm{ha}^{-1}$ was too high. Others have suggested lowering the $\mathrm{N}$ and $\mathrm{P}$ loads by regular manure removal from the pen [9] [44]. However, this study indicated a low effect of such a management strategy, as accumulation of mineral- $\mathrm{N}$ in soil occurred within one month and high loads of $\mathrm{N}$ and $\mathrm{P}$ had an impact on $\mathrm{N}$ and $\mathrm{P}$ contents in surface runoff within two weeks. In practical terms, it would have been difficult for us to carry out frequent manure removal and if done by machinery the soil would have been severely damaged by wheel tracks in the prevailing conditions. Due to cattle behaviour, whereby they spend most time eating and ruminating, a rotational outdoor pen system for conditions such as in this study needs to be so functional that moving feeding and weather shelter areas can be conducted more frequently than once a week to have an environmentally acceptable 
impact. Such functionality was demonstrated in a mobile pen design including shelter and automatic feeding equipment giving outdoor pigs access to a new grazing area each day, which resulted in $\mathrm{N}$ and $\mathrm{P}$ loads comparable with following crop requirements [45].

Almost all mineral $\mathrm{N}$ in topsoil was in $\mathrm{NH}_{4}-\mathrm{N}$ form and, if not nitrified, the risk of direct leaching losses could be expected to be low. The measured $\mathrm{N}_{2} \mathrm{O}$ and $\mathrm{NH}_{3}$ gaseous emissions from the large group pen area were also very low, corresponding to $0.1 \%$ and $2 \%$ of the $\mathrm{N}$ load [46]. The low $\mathrm{N}_{2} \mathrm{O}$ losses might indicate either that nitrification was low or that $\mathrm{NO}_{3}-\mathrm{N}$ was lost through leaching. The concentrations of $\mathrm{NO}_{3}-\mathrm{N}$ in surface runoff increased over winter, but since almost all precipitation became surface runoff, the leaching losses were probably small in this case.

In order to evaluate the risk of $\mathrm{N}$ leaching over the subsequent season, the $\mathrm{N}$ demand of the following crop needs to be considered. The $\mathrm{N}$ load of about $500 \mathrm{~kg} \cdot \mathrm{N} \cdot \mathrm{ha}^{-1}$ in combination with a fertilising effect of the trampled and eventually ploughed-under grass ley would probably be difficult to match with $\mathrm{N}$ uptake by any agricultural crop. Ploughing under grassland in combination with application of animal manure constitutes a considerable risk of N leaching according to e.g. Ulén (1999), who observed increased N leaching during two years after incorporation.

\section{Conclusion}

The rotational system design evaluated in this study was favourable in terms of promoting good animal welfare [23] and reducing the investment, labour and land costs (by 50\%) compared with traditional indoor housing [16]. However, the design did not provide a sufficient distribution of $\mathrm{N}$ and $\mathrm{P}$ excretions, resulting in excessive $\mathrm{N}$ and $P$ loads on certain sub-areas, which was reinforced by the high animal density ( 72 cattle ha $\left.^{-1}\right)$. That, in combination with high precipitation and trampling on an erosion-sensitive soil, had an immediate effect on surface runoff, resulting in high losses of $\mathrm{N}$ and $\mathrm{P}$, where mean losses of total-P was ten times higher than yearly average $\mathrm{P}$ losses from Swedish arable land [11]. The combination of a clay loam soil and wet weather conditions was unfavourable, but not uncommon for the study region (western Sweden) during early winter. In such conditions, this design of outdoor system cannot be used without a risk of negative environmental impact. The challenge is to design a functional and environmental friendly outdoor system which gives access to large areas and where weather shelter and feeding can be highly mobile. Due to expected high runoff in certain periods, the outdoor system should be complemented with vegetation strips close to adjacent surface water bodies. Another approach could be to build a permanent paddock with a comfortable surface layer over an impermeable layer, complemented with a drainage system to collect leachate for storage and subsequent application to crops. However, such an outdoor paddock would need to be cheaper than conventional indoor housing to be interesting to farmers.

\section{Acknowledgements}

This study was funded by The Foundation for Swedish Strategic Environmental Research.

\section{Compliance with Ethical Standards}

Ethical approval was obtained for the project by the ethical committee for animal research.

\section{References}

[1] Eriksen, J. and Kristensen, K. (2001) Nutrient Excretion by Outdoor Pigs: A Case Study of Distribution, Utilization and Potential for Environmental Impact. Soil Use and Management, 17, 21-29. http://dx.doi.org/10.1111/j.1475-2743.2001.tb00004.x

[2] Uusi-Kämppä, J., Jauhiainen, L. and Huuskonen, A. (2007) Phosphorus and Nitrogen Losses to Surface Waters from a Forested Feedlot for Bulls in Finland. Soil Use and Management, 23, 82-91. http://dx.doi.org/10.1111/j.1475-2743.2007.00123.x

[3] Clercq, P.D., et al. (2001) Nutrient Management Legislation in European Countries. Sweden, In: Steineck, S., et al., Eds., Wageningen Pers, Wageningen, 251-280.

[4] SJVFS2013:40 (2013) Föreskrifter om ändring i Statens jordbruksverks föreskrifter och allmänna råd (SJVFS 2004:62) om miljöhänsyn i jordbruket vad avser växtnäring. Statens jordbruksverks författningssamling. 
[5] Djodjic, F. and Kyllmar, K. (2011) Spridning av gödselmedel på åkermark (in Swedish). Department of Aquatic Sciences and Assessments Swedish University of Agricultural Sciences, Report 2011, 22.

[6] Torstensson, G. and Aronsson, H. (2000) Nitrogen Leaching and Crop Availability in Manured Catch Crop Systems in Sweden. Nutrient Cycling in Agroecosystems, 56, 139-152. http://dx.doi.org/10.1023/A:1009821519042

[7] Dahlin, S., Emanuelsson, U. and McAdam, J.H. (2005) Nutrient Management in Low Input Grazing-Based Systems of Meat Production. Soil Use and Management, 21, 122-131. http://dx.doi.org/10.1111/j.1475-2743.2005.tb00416.x

[8] Hynst, J., Šimek, M., Brůček, P. and Petersen, S.O. (2007) High Fluxes but Different Patterns of Nitrous Oxide and Carbon Dioxide Emissions from Soil in a Cattle Overwintering Area. Agriculture, Ecosystems and Environment, 120, 269-279. http://dx.doi.org/10.1016/j.agee.2006.10.003

[9] Airaksinen, S., Heiskanen, M.-L. and Heinonen-Tanski, H. (2007) Contamination of Surface Run-Off Water and Soil in Two Horse Paddocks. Bioresource Technology, 98, 1762-1766. http://dx.doi.org/10.1016/j.biortech.2006.07.032

[10] Cournane, F.C., McDowell, R., Littlejohn, R. and Condron, L. (2011) Effects of Cattle, Sheep and Deer Grazing on Soil Physical Quality and Losses of Phosphorus and Suspended Sediment Losses in Surface Runoff. Agriculture Ecosystems \& Environment, 140, 264-272. http://dx.doi.org/10.1016/j.agee.2010.12.013

[11] Ulén, B. and Jakobsson, C. (2005) Critical Evaluation of Measures to Mitigate Phosphorus Losses from Agricultural Land to Surface Waters in Sweden. Science of the Total Environment, 344, 37-50. http://dx.doi.org/10.1016/j.scitotenv.2005.02.004

[12] Kumm, K.-I., et al. Future Scenarios for Sustainable Swedish Beef Production. Food 21 No. 12005, Swedish Univesity of Agricultural Sciences, Uppsala, 1-18.

[13] Keeling, L. and Jensen, P. (2002) Behavioural Disturbances, Stress and Welfare. In: Jensen, P., Ed., The Ethology of Domestic Animals: An Introductory Text, CABI, Wallingford, 79-98. http://dx.doi.org/10.1079/9780851996028.0079

[14] Oudshoorn, F., Kristensen, T. and Shahrak Nadimi, E. (2008) Dairy Cow Defecation and Urination Frequency and Spatial Distribution in Relation to Time-Limited Grazing. Livestock Science, 113, 62-73. http://dx.doi.org/10.1016/j.livsci.2007.02.021

[15] Owens, L.B. and Shipitalo, M.J. (2009) Runoff Quality Evaluations of Continuous and Rotational Over-Wintering Systems for Beef Cows. Agriculture, Ecosystems and Environment, 129, 482-490. http://dx.doi.org/10.1016/j.agee.2008.11.003

[16] Salomon, E., Kumm, K.-I., Lidfors, L., Lindgren, K. and Torstensson, G. (2012) A Rotational Grazing System for Beef Cattle during Winter-Effect on Production Cost in Relation to Animal Welfare, Working Environment and Environmental Impact. In: Rahmann, G. and Godhino, D., Eds., Tackling the Future Challenges of Organic Animal Husbandry, Proceedings of the 2nd OAHC, Hamburg/Trenthorst, 12-14 September 2012, 93-96.

[17] SCB (2010) Jordbruksstatistisk Årsbok 2010. JO01BR10012010, Statistics Sweden Stockholm, 1-388.

[18] Alexandersson, H., Karlström, C. and Larsson-McCann, S. (1991) Temperaturen och nederbörden i Sverige 1961-90. Referensnormaler. The Swedish Meteorological and Hydrological Institute (SMHI), Norrköping, 1-88.

[19] SGU (2010) Sveriges Geologiska Undersökningar, Uppsala. http://www.maps.sgu.se

[20] FAO (1998) World Reference Base for Soil Resources. World Soil Resources, Rome, 1-88.

[21] ISO (2005) Soil Quality-Determination of pH. 2nd Edition, International Organization for Standardization, Geneva.

[22] Damgaard-Poulsen, H. and Friis Kristensen, V. (Eds.) (1998) Standard Values for Farm Manure. DIAS Report No. 7, Animal Husbandry, Ministry of Food, Agriculture and Fisheries Denmark, Tjele, 1-107.

[23] Wahlund, L., Lindgren, K., Salomon, E. and Lidfors, L. (2010) Behavior in Two Group Sizes of Beef Cattle Kept in a Mobile Outdoor System during Winter. Proceedings of the 44th Congress of the International Society for Applied Ethology (ISAE), Uppsala, 4-7 August 2010, 101.

[24] Benfalk, C., Lindgren, K., Lindahl, C. and Rundgren, M. (2005) Mobile and Stationary Systems for Organic PigsAnimal Behaviour in Outdoor Pens. In: Köpke, U., Niggli, U., Neuhoff, D., Cornish, P., Lockeretz, W., Willer, H., Eds., Researching Sustainable Systems, 242-245.

[25] Salomon, E., Åkerhielm, H., Lindahl, C. and Lindgren, K. (2007) Outdoor Pig Fattening at Two Swedish Organic Farms-Spatial and Temporal Load of Nutrients and Potential Environmental Impact. Agriculture, Ecosystems \& Environment, 121, 407-418. http://dx.doi.org/10.1016/j.agee.2006.11.017

[26] APHA (1985) Standard Methods for the Examination of Water and Waste Water. American Public Health Association, New York.

[27] ECS (1996) Water Quality. Determination of Phosphorus. Ammonium Molybdate Spectrometric Method. European Standard. EN 1189, ECS-European Committee for Standardization, Brussels.

[28] Frank, A. (1976) Automated Wet Ashing and Multi-Metal Determination in Biological Material by Atomic-Absorption 
Spectrometry. Fresenius' Zeitschrift für analytische Chemie, 279, 101-102. http://dx.doi.org/10.1007/BF00440775

[29] Frank, A. (1983) Alltid viss risk? (Always Risky?_Wet Ashing with Perchloric Acid). Ken. Tidsk, 95, 63.

[30] Lindén, B. (1977) Equipment for Sampling in Agricultural Soils. Division of Soil Fertility Swedish University of Agricultural Sciences, Uppsala, 1-29.

[31] Bremner, J.M. and Keeney, D.R. (1996) Determination and Isotope-Ratio Analysis for Different Forms of Nitrogen in Soils: 3. Exchangeable Ammonium, Nitrate, and Nitrite by Extraction-Distillation Methods. Proceedings of the Soil Science Society of America, 30, 577-582. http://dx.doi.org/10.2136/sssaj1966.03615995003000050015x

[32] Aronsson, H. and Torstensson, G. (1998) Measured and Simulated Availability and Leaching of Nitrogen Associated with Frequent Use of Catch Crops. Soil Use and Management, 14, 6-13. http://dx.doi.org/10.1111/j.1475-2743.1998.tb00603.x

[33] Egnér, H., Riehm, H. and Domingo, W.R. (1960) Untersuchungen über die chemische Bodenanalyse als Grundlage für die Beurteilung des Nährstoffzustandes der Böden. II. Chemische Extraktionsmethoden zur Phosphor- und Kaliumbestimmung. Kungliga Lantbrukshögskolans Annaler, 26, 199-215.

[34] KLS (1965) National Board of Agriculture. Circular No. 1, Solna, 20.

[35] SS (1993) SS 028310. Soil Analysis_Extraction and Determination of Phosphorus, Potassium, Calcium, Magnesium and Sodium from Soils with Ammonium Lactate/Acetic Acid Solution (the AL-Method): The Standardising Commission in Sweden, Stockholm. (In Swedish)

[36] Minitab (1999) Minitab Statistical Software Release 13 for Windows. Minitab Inc., State College.

[37] Tisdall, J.M. and Oades, J.M. (1982) Organic Matter and Water-Stable Aggregates in Soils. Journal of Soil Science, 33, 141-163. http://dx.doi.org/10.1111/j.1365-2389.1982.tb01755.x

[38] Lundekvam, H. and Skøien, S. (1998) Soil Erosion in Norway. An Overview of Measurements from Soil Loss Plots. Soil Use and Management, 14, 84-89. http://dx.doi.org/10.1111/j.1475-2743.1998.tb00620.x

[39] Parvage, M., Kirchmann, H., Kynkäänniemi, P. and Ulén, B. (2011) Impact of Horse Grazing and Feeding on Phosphorus Concentration in Soil and Drainage Water. Soil Use and Management, 27, 367-375. http://dx.doi.org/10.1111/j.1475-2743.2011.00351.x

[40] Turtola, E. and Kemppainen, E. (1998) Nitrogen and Phosphorus Losses in Surface Runoff and Drainage Water after Application of Slurry and Mineral Fertilizer to Perennial Grass Ley. Agricultural and Food Science in Finland, 7, 569581.

[41] Turtola, E. and Jaakkola, A. (1995) Loss of Phosphorus by Surface Runoff and Leaching from a Heavy Clay Soil under Barley and Grass Ley in Finland. Acta Agriculturae Scandinavica Section B, Soil and Plant Science, 45, 159-165.

[42] 91/676/EEC (1991) Council Directive 91/676/EEC of 12 December 1991 Concerning the Protection of Waters against Pollution Caused by Nitrates from Agricultural Sources. 1-90. http://eur-lex.europa.eu/LexUriServ/LexUriServ.do?uri=CELEX:52010DC0047:EN:NOT

[43] Sørensen, P. and Rubaek, G.H. (2012) Leaching of Nitrate and Phosphorus after Autumn and Spring Application of Separated Solid Animal Manures to Winter Wheat. Soil Use and Management, 28, 1-11. http://dx.doi.org/10.1111/j.1475-2743.2011.00382.x

[44] Uusi-Kämppä, J. (2002) Nitrogen and Phosphorus Losses from a Feedlot for Suckler Cows. Agricultural and Food Science in Finland, 11, 355-369.

[45] Salomon, E., Andresen, N., Gustafsson, M., Nyman, M., Ringmar, A. and Tersmeden, M. (2008) Development of a Mobile Organic Piggery for Outdoor Pork Production-Function, Productivity, Animal Behaviour and Environmental Risk Assessment. Proceedings of 16th IFOAM Organic World Congress, Modena, 16-20 June 2008. http://orgprints.org/11626

[46] Salomon, E. and Rodhe, L. (2011) Losses of $\mathrm{N}_{2} \mathrm{O}, \mathrm{CH}_{4}$ and $\mathrm{NH}_{3}$ from a Grass Sward Used for Overwintering Beef Heifers. Animal Feed Science and Technology, 166-167, 147-154. http://dx.doi.org/10.1016/j.anifeedsci.2011.04.008 